\title{
Ekspresi Prethrombin-2 Manusia Recombinan dalamPichia pastoris dan Optimasi Kondisi Ekspresinya
}

\author{
Shabarni Gaffar, Purba Upay, Wulan Pertiwi, Iman Permana Maksum, Khomaini \\ Hasan, Toto Subroto, Sutarya Enus dan Soetijoso Soemitro \\ Departemen Kimia, Fakultas Matematika dan Ilmu Pengetahuan Alam, Universitas \\ Padjadjaran, Jatinangor. Indonesia. \\ E-mail : shabarni.gaffar@unpad.ac.id
}

\begin{abstract}
Abstrak
Pretrombin merupakan prekursor dari trombin yang memiliki aktivitas proteolitik. Trombin merubah fibrinogen menjadi benang fibrin yang salah satu aplikasinya adalah dapat digunakan sebagai lem untuk menggantikan teknik jahitan pasca bedah. Aplikasi trombin untuk pembuatan lem fibrin menuntut diproduksinya trombin rekombinan. Tujuan dari penelitian ini adalah ekspresi gen pretrombin-2 (PT2) manusia rekombinan menggunakan sistem ekspresi Pichia pastoris. Gen pengode PT2 dirancang sesuai dengan kodon preferensi P. pastoris. Fragmen PT2 diamplifikasi dengan metoda PCR dengan penambahan sisi restriksi EcoR1 pada ujung 5' dan sisi restriksi SacII pada ujung 3'. Produk PCR yang berukuran 924 pb diligasi dengan vektor ekspresi pPICZaB untuk P. pastoris dan disubkloning dalam inang Escherichia coli. Urutan nukleotida dikonfirmasi dengan metoda dideoxy Sanger. Plasmid rekombinan pPICZaBPT2 kemudian digunakan untuk mentransformasi P. pastoris SMD1168 defisien protease dengan metoda elektroporasi. Hasil penelitian menunjukkan bahwa gen PT2 berhasil diamplifikasi dan dikloning dalam E. coli. Analisis restriksi dan penentuan urutan DNA menunjukkan bahwa PT2 rekombinan 100\% homologi dengan hasil rancangan. Hasil ekspresi PT2 oleh P. pastoris menggunakan metanol sebagai inducer memperlihatkan bahwa PT2 dengan berat molekul $35 \mathrm{kDa}$ berhasil diekspresikan. Optimasi kondisi ekspresi melalui variasi konsentrasi metanol sebagai inducer dan sorbitol sebagai sumber karbon tambahan menunjukkan bahwa metanol 2\% dan sorbitol 2\% merupakan kondisi optimum ekspresi PT2.
\end{abstract}

Kata kunci : Pretrombin-2, trombin, Pichia pastoris, kondisi ekspresi

\section{Expression of Human Prethrombin-2 Recombinant in Pichia pastoris and Optimization of Expression Condition}

\begin{abstract}
Prethrombin is precursor of thrombin that has the proteolysis activity. Thrombin with fibrinogen will form fibrin threads that one of the application is can be used as a glue to substitute post-operative suture technique. The application of thrombin for making of fibrin glue needs the production of recombinant thrombin. The purpose of this study was to express the prethrombin-2 (PT2) gene in Pichia pastoris expression system. The synthetic PT2 was constructed to has optimized codon according to codon preference of P. pastoris. PT2 fragment was amplified by PCR method with the addition of EcoRI site at 5 ' end and SacII site at 3' end. The 924 bp of PCR product was subclonned in Escherichia coli, then was ligated into pPICZaB expression vector and cloned in E. coli. The nucleotide sequences were confirmed by Sanger dideoxy sequencing method. The pPICZaB-PT2 recombinant plasmid then was used to transform protease deficient P. pastoris SMD1168 by electrophoration method. The results showed that PT2 gene has been successfully amplified and cloned in E. coli. Restriction analysis and DNA sequence determination showed that the sequence of PT2 recombinant has $100 \%$ homology with the design. Expression of PT2 by P. pastoris by using methanol as inducer showed that $35 \mathrm{kDa}$ of PT 2 was successfully expressed in P. pastoris. Optimazion of expression condition shows that $2 \%$ inducer concentration and addition of $2 \%$ sorbitol as additional carbon source were the optimum condition for PT2 expression.
\end{abstract}

Keywords: Prethrombin-2, thrombin, Pichia pastoris, expression condition. 


\section{Pendahuluan}

Trombin merupakan enzim kunci pada proses hemostatis dan berperan pada beberapa substrat yang terlibat pada proses pembekuan darah. ${ }^{1,2}$ Pretrombin-2 adalah zymogen prekursor dari trombin. Pretrombin-2 memiliki 308 asam amino dan terdiri dari rantai A dan B yang dihubungkan oleh empat ikatan disulfida dan mengandung satu sisi glikosilasi. ${ }^{3}$

Trombin merupakan suatu protease serin multifungsi yang termasuk golongan tripsin. Trombin memiliki berbagai macam sifat dan interaksi biokimia yang berperan sebagai prokoagulan dan antikoagulan. ${ }^{4}$ Trombin memiliki aplikasi yang luas, diantaranya: dibidang kesehatan dan pembedahan, pada penelitian biologi molekul trombin digunakan sebagai protein fusi pada produksi protein rekombinan dan pada produksi makanan trombin digunakan sebagai agen pengikat daging. ${ }^{5}$

Protein terapeutik yang terglikosilasi pada umumnya diproduksi menggunakan sistem ekspresi mamalia dengan tujuan untuk memperoleh protein yang autentik. Sel CHO (Chinesse Hamster Ovary) paling banyak digunakan untuk ekspresi protein mamalia. Trombin manusia rekombinan yang pertama terdaftar diproduksi dari prekursor protrombin-1 dalam inang CHO. ${ }^{6}$ Hasil uji klinis menunjukkan bahwa produk ini toleran terhadap proteolisis. Namun inang ekspresi ini mahal dan nilai ekonominya rendah.

Ragi metilotropik P. pastoris sering digunakan sebagai inang untuk ekspresi protein rekombinan karena tingkat ekspresinya yang tinggi. P. pastoris cocok digunakan untuk produksi protein eukariot dengan folding yang tepat dan protein yang membutuhkan modifikasi pasca translasi. ${ }^{7,8}$ Lebih dari 550 protein heterolog telah berhasil disintesis dan diproduksi dalam ragi P. pastoris. ${ }^{9}$ Beberapa protein terapi yang diproduksi dalam P. pastoris, baik yang tidak terglikosilasi (seperti serum albumin manusia) ${ }^{10}$ atau protein yang memerlukan glikosilasi untuk pelipatan (seperti beberapa vaksin $)^{11}$ sudah beredar dipasaran.

Pada penelitian ini pretrombin-2 manusia diekspresikan dalam inang $P$. pastoris. Ekspresi pretrombin-2 dalam inang P. pastoris memungkinkan sekresi ekstraselular dengan tersedianya vektor ekspresi yang mengandung peptida sinyal yaitu pPICZaB. Selain itu inang P. pastoris defisien protease dipilih untuk meminimalkan proteolisis hasil ekspresi. Inang ini berhasil digunakan untuk ekspresi endostatin manusia.?

\section{Metode Penelitian}

Galur, vektor dan reagen.

Fragmen gen PT2 dirancang sesuai kodon preferensi P. pastoris dan disintesis oleh DNA 2.0 (California). P. pastoris galur SMD1168 dan E. coli galur TOP10F' dari Invitrogen. Vektor pPICZ $\alpha \mathrm{B}$ dari Invitrogen dan vektor pJet1.2 dari Thermo Scientific. Enzim restriksi endonuklease, Taq DNA polymerase, dan T4 DNA ligase dari Thermo Scientific. Primer PCR dan sekuensing DNA disintesis oleh FirstBase (Singapura). Kit isolasi DNA dan purifikasi DNA dari TianGene. Semua zat kimia yang digunakan dari Sigma. Media pertumbuhan yang digunakan adalah YPD (ekstrak ragi $1 \%$, pepton $2 \%$, dekstrosa $2 \%$ ), YPDS (ekstrak ragi $1 \%$, pepton $2 \%$, dekstrosa $2 \%$, sorbitol $1 \mathrm{M}$, bakto agar $2 \%$ ), BMGH (Buffered Minimal Glycerol Histidine): (ekstrak ragi $1 \%$, pepton $2 \%$, kalium fosfat $100 \mathrm{mM}$ pH 6,0 , YNB $1,43 \%$, biotin $4 \mathrm{x}$ $10-5 \%$, histidin $4 \times 10-3 \%$ dan gliserol 1\%). BMMH (buffered minimal methanol histidine): YNB 1,43\%, kalium fosfat 100 $\mathrm{mM}$ pH 6,0, biotin $4 \times 10-5 \%$, metanol 1\%, dan histidin 4 x 10-3\%. Bahan untuk media pertumbuhan diperoleh dari Oxoid.

Konstruksi plasmid pPICZ $\alpha \mathrm{B}-\mathrm{PT} 2$.

Fragmen PT2 diamplifikasi dari templat gen PT2 sintetik dengan penambahan sisi restriksi EcoR1 pada ujung 5' dan SacII pada ujung 3'. Enzim restriksi ini dipilih dari hasil analisis urutan PT2 dan menyesuaikan 
dengan MCS pada vektor pPICZ $\alpha \mathrm{B}$. PCR dilakukan menggunakan pasangan primer 5'EcoPT2 dan 3'PT2Sac. Produk PCR ( $\sim 924 \mathrm{pb})$ dikloning menggunakan vektor pJet1.2 menghasilkan plasmid rekombinan pJet1.2-PT2. Selanjutnya, plasmid pJet1.2PT2 direstriksi menggunakan enzim restriksi EcoR1 dan SacII, dimurnikan dan diinsersi ke sisi yang sama pada vektor $\mathrm{pPICZ} \alpha \mathrm{B}$ untuk menghasilkan plasmid pPICZaBPT2. Urutan nukleotida diverifikasi dengan sekuensing DNA.

\section{Transformasi P. pastoris.}

Sel inang P. pastoris defisien protease SMD1168 ditransformasi dengan metoda elektroporasi. Sel kompeten disiapkan mengikuti protokol.12 Sebanyak $50 \mu \mathrm{L}$ sel kompeten dicampur dengan 1-5 $\mu \mathrm{g}$ plasmid rekombinan pPICZ $\alpha$ B-PT2 yang telah dilinearkandenganPme1.Seldielektroporasi selama 5 milidetik dengan kuat arus $1,5 \mathrm{kV} /$ $\mathrm{cm}$ menggunakan Eppendorf Electroporator 2510. Transforman P. pastoris ditumbuhkan pada media YPDS dengan penambahan antibiotik zeocin $100 \mu \mathrm{g} / \mathrm{mL}$, dan diinkubasi selama 3 hari pada suhu $30^{\circ} \mathrm{C}$.

Pembuatan Kurva Pertumbuhan.

P. pastoris ditumbuhkan pada media YPD cair selama semalam, $1 \mathrm{~mL}$ kultur dipindahkan ke dalam $100 \mathrm{~mL}$ media BMGH dengan dan tanpa penambahan sorbitol 2\% dalam labu erlenmeyer 100 mL. ${ }^{13}$ Kultur diinkubasi pada suhu $28^{\circ} \mathrm{C}$ dalam inkubator pengocok pada kecepatan $200 \mathrm{rpm}$. OD600 ditentukan setiap tiga jam.

\section{Penentuan Konsentrasi Penginduksi} Metanol.

P. pastoris ditumbuhkan dalam media YPD cair $5 \mathrm{~mL}$, diinkubasi pada suhu $30^{\circ} \mathrm{C}$ dengan kecepatan pengocokan $250 \mathrm{rpm}$ selama 16-18 jam. Satu mL kultur hasil inokulasi dipindahkan ke dalam empat labu yang berisi $100 \mathrm{~mL}$ media BMGH dengan penambahan sorbitol $2 \%$ dalam labu 500 $\mathrm{mL}$, diinkubasi pada suhu $28^{\circ} \mathrm{C}$ dengan kecepatan 200 rpm selama 72 jam. Kultur disentrifugasi dengan kecepatan $6000 \mathrm{rpm}$ selama 5 menit pada suhu ruang. Supernatan didekantasi dan pelet sel diresuspensi dalam media BMMH dengan volume 1/10 kultur $( \pm 10 \mathrm{~mL})$. Inkubasi dilanjutkan pada suhu $28^{\circ} \mathrm{C}$ dalam inkubator pengocok dengan kecepatan $200 \mathrm{rpm}$. Metanol ditambahkan hingga konsentrasi akhir 0,75\%, 1,5\%, $2 \%$, dan 3\% setiap 24 jam. Sampel diambil setiap 24 jam pada waktu penambahan metanol (24, 48, 72, 96,120, dan 144 jam), OD600 ditentukan, pelet dipisahkan dari supernatan dengan sentrifugasi, disimpan pada suhu $-20^{\circ} \mathrm{C}$ sebelum dianalisis.

\section{Optimasi Ekspresi Variasi Konsenstrasi Sorbitol}

P. pastoris ditumbuhkan dalam $5 \mathrm{~mL}$ media YPD cair diinkubasi pada suhu $30^{\circ} \mathrm{C}$ dengan kecepatan pengocokan 250 rpm selama 16-18 jam. Satu mL kultur dipindahkan ke dalam $100 \mathrm{~mL}$ media BMGH dan ditambah sorbitol masingmasing dengan konsentrasi $1 \%, 2 \%$, dan $3 \% \quad(\mathrm{v} / \mathrm{v})$ dalam labu Erlenmeyer 500 $\mathrm{mL}$, diinkubasi pada suhu $28^{\circ} \mathrm{C}$ di dalam inkubator pengocok dengan kecepatan $\sim 200$ rpm selama 72 jam. Kultur P. pastoris dari media $\mathrm{BMGH}$ disentrifugasi dengan kecepatan 6000 rpm selama 5 menit pada suhu ruangan. Supernatan didekantasi dan pelet sel diresuspensi dalam media BMMH dengan volume 1/10 kultur $\mathrm{BMGH}( \pm 10$ $\mathrm{mL}$ ). Inkubasi dilanjutkan kembalipada suhu $28^{\circ} \mathrm{C}$ dalam inkubator pengocok dengan kecepatan $\sim 200 \mathrm{rpm}$. Metanol ditambahkan hingga konsentrasi akhir $0,75 \%$ setiap 24 jam. Sampel diambil setiap 24 jam pada waktu penambahan metanol $(24,48,72$, 96, 120, dan 144 jam), pelet dipisahkan dari supernatan dengan sentrifugasi, disimpan pada suhu $-20^{\circ} \mathrm{C}$ sebelum dianalisis.

\section{Analisis SDS-PAGE.}

Sodium dodecyl sulfate polyacrylamide gel electrophoresis dilakukan pada kondisi tereduksi menggunakan running gel 10\% dan stacking gel 4\%. Dua puluh lima mikro liter supernatan transforman $\mathrm{P}$. pastoris 
dianalisis dengan SDS-PAGE. Pita protein pada gel dideteksi dengan pewarnaan Coomassie brilliant blue.

Penentuan Kadar Protein.

Kadar protein ditentukan dengan metoda Lawry. ${ }^{14}$ Kurva standar dibuat menggunakan BSA.

\section{Hasil}

Konstruksi plasmid rekombinan pPICZ $\alpha \mathrm{B}-$ PT2 dan kloning dalam E. coli.

Fragmen PT2 dengan ukuran 924 pb berhasil diamplifikasi dengan metoda PCR (Gambar 1). Fragmen DNA dimurnikan dan dikloning menggunakan vektor pJet1.2 dalam inang E. coli TOP10F'. Plasmid pJet1.2-PT2 diisolasi dari transforman E. coli, kemudian direstriksi menggunakan enzim EcoR1 dan SacII mengikuti protokol. Hasil analisis restriksi pada beberapa plasmid dari koloni transforman E. coli menunjukkan bahwa dari empat koloni yang dianalisis, tiga koloni membawa plasmid rekombinan pJet1.2-PT2.

Fragmen PT2 hasil restriksi kemudian diligasi ke sisi yang sama pada vektor pPICZ $\alpha \mathrm{B}$ dan disubkloning dalam inang E. coli TOP10F'. Plasmid pPICZ $\alpha$ BPT2 diisolasi untuk dianalisis restriksi dan penentuan urutan nukleotida, hasil penentuan urutan nukleotida menunjukkan bahwa urutan PT2 hasil kloning sesuai dengan rancangan (data tidak diperlihatkan).

Pada Gambar 2 diperlihatkan hasil analisis restriksi dan peta plasmid rekombinan pPICZ $\alpha$ B-PT2 hasil konstruksi. Hasil analisis restriksi dari empat koloni menunjukkan bahwa semua koloni membawa plasmid rekombinan.

\section{Kurva pertumbuhan P. pastoris SMD} 1168[PT2]

Perbandingan kurva pertumbuhan $\mathrm{P}$. pastoris dalam media $\mathrm{BMGH}$ dan $\mathrm{BMGH}$ ditambah sorbitol 2\% menunjukkan bahwa penambahan sorbitol sedikit meningkatkan densitas sel P. pastoris SMD1168 (Gambar 3). Hasil ini berbeda dengan penambahan sorbitol pada inang P. pastoris GS115 yang dapat meningkatkan densitas sel sampai dua kali lipat.13 P. pastoris SMD 1168 merupakan inang defisien protease yang menunjukkan pertumbuhan yang lambat dibanding P. pastoris GS115.7 Sumber karbon tambahan yang tidak menghambat promotor AOX diperlukan untuk meningkatkan densitas sel sehingga dapat meningkatkan level ekspresi.8 Penambahan sumber karbon sorbitol juga meningkatkan pertumbuhan inang $\mathrm{P}$. pastoris defisien protease.15 OD600 terlihat meningkat sampai jam ke-21 (Gambar 3). P. pastoris bukan merupakan ragi fermentatif, yaitu tidak menghasilkan etanol yang bersifat

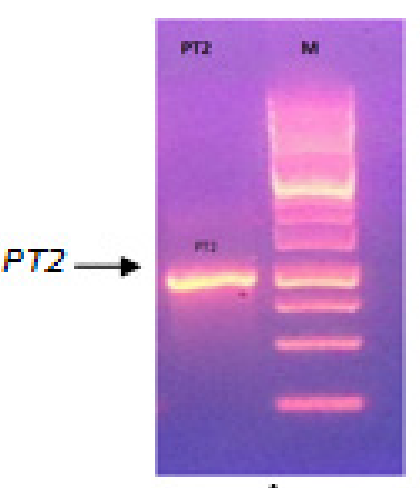

A.

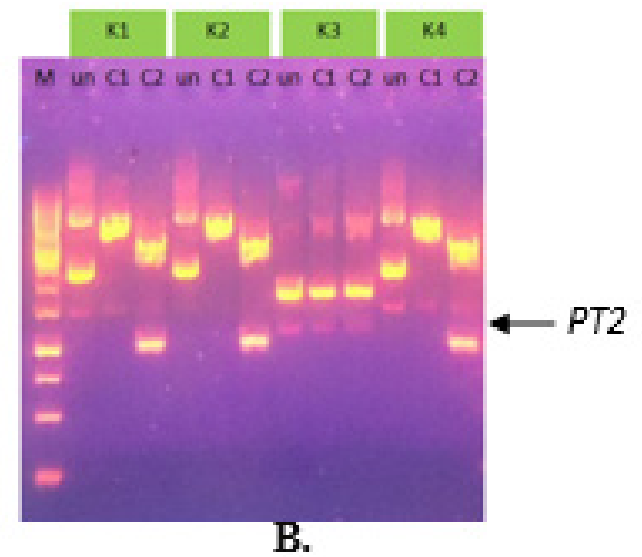

Gambar 1.A. Produk PCR PT2 ( 924 pb). B. Hasil isolasi DNA plasmid rekombinan pJet1.2-PT2 dan analisis restriksi dari koloni-koloni transforman, $\mathrm{M}=\mathrm{DNA}$ marker, un=plasmid sirkular, $\mathrm{C} 1=$ plasmid dipotong dengan enzim EcoR1, C2= plasmid dipotong dengan enzim EcoR1 dan SacII. 

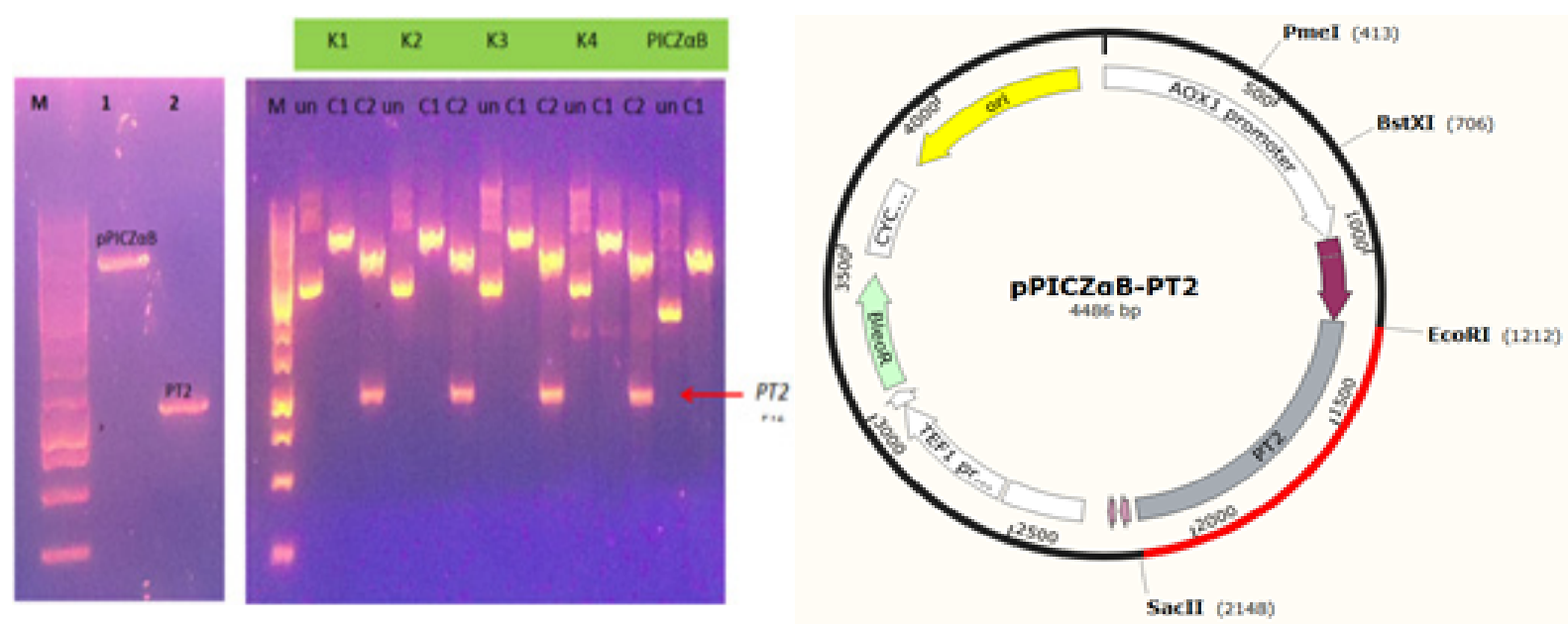

Gambar 2. A. Fragmen DNA pPICZaB dan PT2 hasil restriksi dengan enzim EcoR1 dan SacII; B. Hasil isolasi DNA plasmid rekombinan pPICZ $\alpha \mathrm{B}-\mathrm{PT} 2$ dan analisis restriksi dari koloni-koloni transforman, $\mathrm{M}=$ DNA marker, un=plasmid sirkular, $\mathrm{C} 1=$ plasmid dipotong dengan enzim EcoR1, C2= plasmid dipotong dengan enzim EcoR1 dan SacII; C. Peta plasmid rekombinan pPICZaB-PT2.

racun bagi sel, sehingga dapat ditumbuhkan hingga mencapai densitas sel yang tinggi. ${ }^{7}$

Ekspresi Pretrombin-2 oleh inang P. pastoris SMD 1168.

Hasil ekspresi pretrombin-2 oleh P. pastoris SMD 1168 menggunakan media BMGH + sorbitol $2 \%$ dan media ekspresi $\mathrm{BMMH}$ serta penginduksi metanol 0,75\%. Induksi dilakukan setiap 24 jam sampai jam ke-144. Terlihat bahwa PT2 dengan BM $35 \mathrm{kDa}$ berhasil diekspresikan secara ekstraselular mulai pada jam ke-24 sampai jam ke-144 dengan tingkat ekspresi yang relatif sama (Gambar 4).

Optimasi konsentrasi penginduksi

Konsentrasi optimum penginduksi ditentukan dengan variasi konsentrasi metanol $0,75 \%, 1 \%, 1,5 \%, 2 \%$ dan $3 \%$. Ekspresi dilakukan seperti prosedur menggunakan media BMGH + sorbitol 2\% dan inducer ditambahkan setiap jam sampai jam ke 144. Hasil pengaruh konsentrasi inducer ditampilkan pada diagram batang Gambar 5. Terlihat bahwa pada konsentrasi penginduksi $2 \%$ kadar protein yang dihasilkan jauh lebih tinggi dibandingkan dengan yang lain.

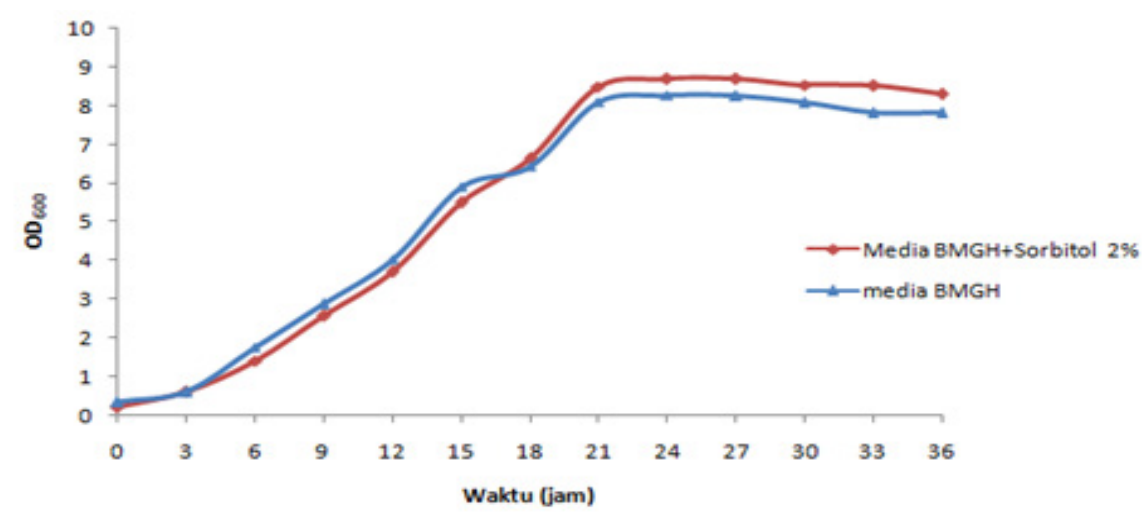

Gambar 3.Kurva pertumbuhan P. pastoris SMD 1168[PT2] dalam media BMGH (biru) dan BMGH + sorbitol 2\% (merah). 


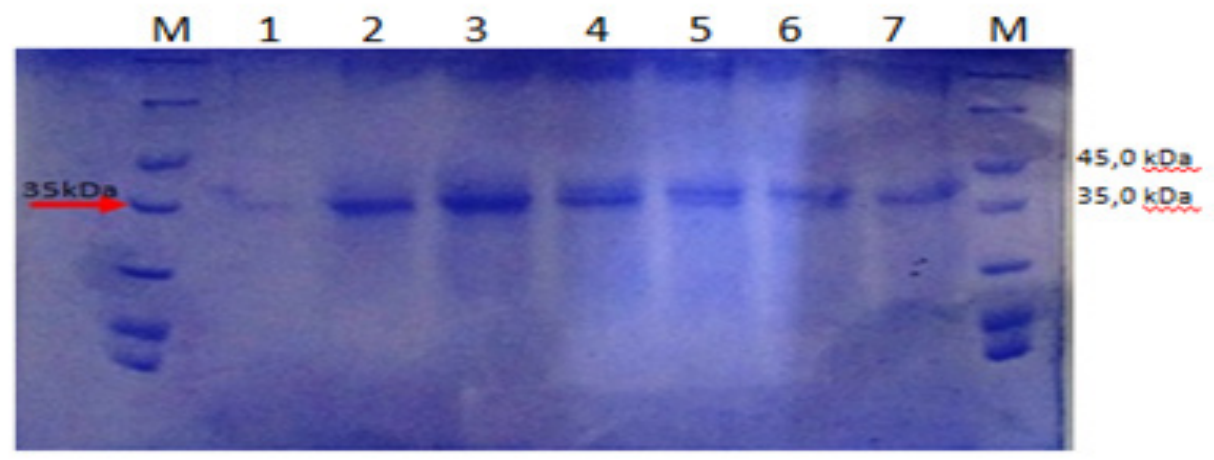

Gambar 4. Elektroforegram SDS-PAGE pretrombin-2 manusia rekombinan hasil ekspresi dari P. pastoris SMD1168 dengan penambahan sorbitol 2\% dan pengiduksi metanol $2 \%$. (M) marker protein; (1) sebelum diinduksi; (2) jam ke-24; (3) jam ke-48; (4) jam ke-72; (5) jam ke-96; (6) jam ke-120; (7) jam ke-144.

Optimasi konsentrasi sorbitol

Hasil ekspresi PT2 dengan variasi konsentrasi sorbitol sebagai sumber karbon tambahan memperlihatkan konsentrasi sorbitol 2\% merupakan konsentrasi yang optimum (Gambar 6).

\section{Pembahasan.}

Pretrombin-2 dengan berat molekul $35 \mathrm{kDa}$ berhasil diekspresikan secara ekstraselular menggunakan inang P. pastoris SMD 1168 defisien protease. Penggunaan inang defisien protease bertujuan untuk menghindari proteolisis, namun P. pastoris SMD 1168 pertumbuhannya lambat, walaupun dengan sumber karbon tambahan. Terlihat pada penelitian ini bahwa OD pada fasa logaritma meningkat dengan lambat sehingga diperlukan waktu yang lama untuk mendapatkan densitas sel yang tinggi. Densitas sel yang tinggi diperlukan untuk ekspresi level tinggi, karena $P$. pastoris bukan merupakan ragi fermentatif, sehingga $\mathrm{P}$. pastoris tidak menghasilkan etanol yang merupakan racun bagi sel.

Ekspresi pretrombin-2 secara ekstraselular bertujuan untuk memudahkan pemurnian protein, Pretrombin-2 ditemukan pada media pertumbuhan dengan kadar protein tertinggi adalah $1000 \mathrm{mg} / \mathrm{L}$. Hasil ini relatif rendah, dibandingkan dengan ekspresi tinggi protein rekombinan yang pernah dilaporkan sebelumnya, seperti Human necrosis factor (10.000 mg/L) (Daly

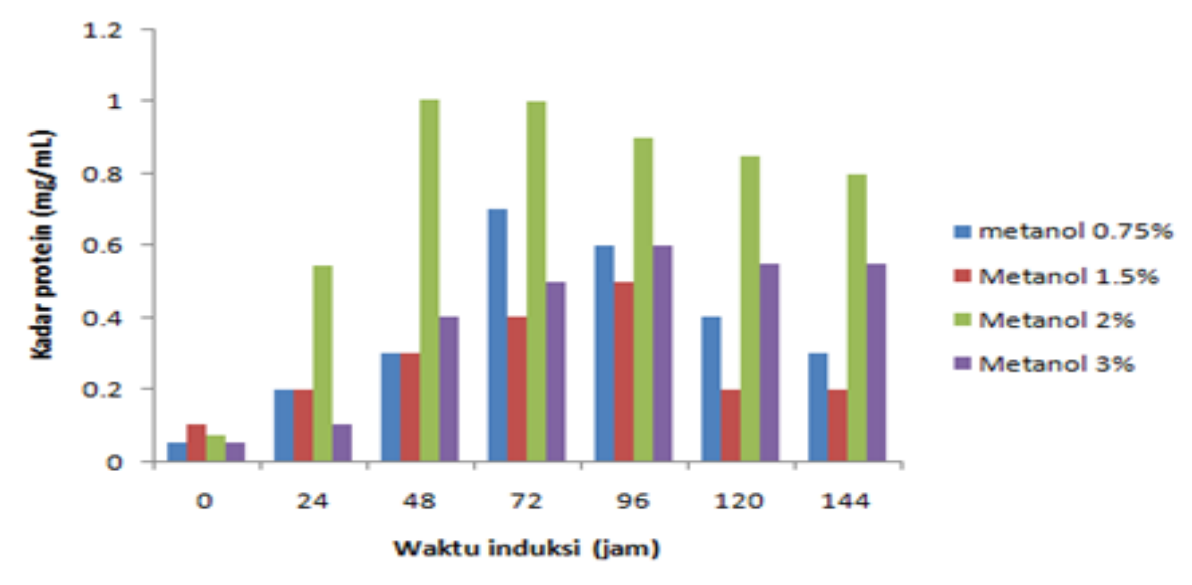

Gambar 5. Perbandingan hasil ekspresi PT2 oleh P. pastoris SMD 1168 dengan variasi konsentrasi penginduksi metanol. Kadar protein ditentukan dengan metoda Lawry. 


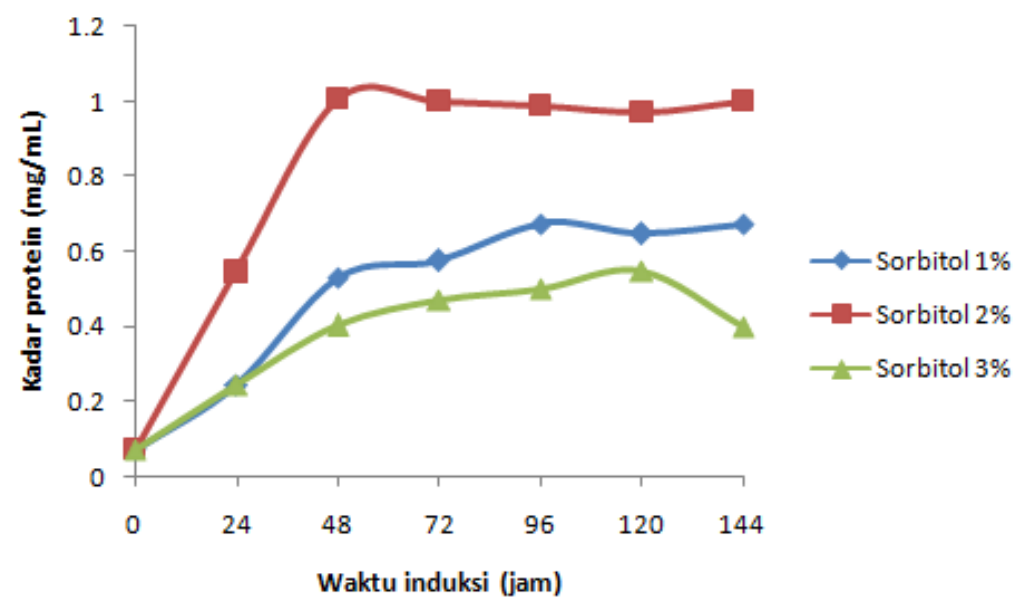

Gambar 6. Perbandingan kadar protein PT2 hasil ekspresi dengan variasi penambahan sorbitol 1\% (merah), 2\% (biru), 3\% (hijau). Kadar protein ditentukan dengan metoda Lawry.

\& Hearn, 2005). Penggunakan sumber karbon dan sumber nitrogen lainnya perlu dipelajari untuk meningkatkan ekspresi pretrombin-2 oleh P. pastoris.

Pretrombin-2 adalah prekursor trombin. Aktivasi pretrombin-2 menjadi trombin terjadi melalui pemotongan pada residu Arginin ke 320 (penomoran pada asam amino pro-trombin) oleh protrombinase atau dengan ekarin. Aktivasi pretrombin-2 rekombinan yang dihasilkan perlu diuji untuk membuktikan apakah P. pastoris menghasilkan pretrombin-2 dengan folding yang tepat.

Penelitian ini menunjukkan bahwa sorbitol merupakan sumber karbon tambahan yang bersifat non-represif, yaitu dapat meningkatkan pertumbuhan dan tidak menghambat ekspresi protein asing. Sorbitol sudah diketahui dapat digunakan sebagai sumber karbon tambahan pada produksi $\beta$-galaktosidase rekombinan dalam sistem ekspresi P. pastoris dibawah kontrol promotor AOX1. Namun konsentrasi optimum sumber karbon tambahan dipengaruhi oleh inang yang digunakan dan protein rekombinan yang diekspresikan (Inan \& Meager, 2001).

\section{Kesimpulan.}

Pretrombin-2 manusia rekombinan berhasil diekspresikan dalam inang $P$. pastoris SMD 1168 dengan konsentrasi penginduksi optimum $2 \%$ dan sorbitol $2 \%$ sebagai sumber karbon tambahan.

\section{Ucapan Teriman kasih.}

Penelitian ini dilaksanakan dengan dana Penelitian Unggulan Nasional Dikti 20132015.

\section{Daftar Pustaka}

1. Giulia Russo, Alain Gast, Ernst-Jurgen Schlaeger, Antonietta Angiolillo, and Concetta Pietropaolo. Stable Expression and Purification of a Secreted Human Recombinant Prethrombin-2 and Its Activation to Thrombin. Protein expression and purification. 1997;10, 214-225.

2. Crawley, JT, Zanardelli, S, Chion, CK, Lane DA. 2007. The central role of thrombin in hemostasis.J Thromb Haemost: 5 Suppl 1:95-101. DOI:10.1111/j.15387836.2007.02500.x

3. Pozzi N, Chen Z, Zapata F, Pelc LA, Barranco-Medina S, Di Cera E. Crystal structures of prethrombin-2 reveal alternative conformations under identical solution conditions and the mechanism of zymogen activation. Biochemistry. 2011;50(47):10195-202. doi: 10.1021/bi2015019. 
4. Di Cera E.Thrombin as procoagulant and anticoagulant.J Thromb Haemost;5 Suppl. 2007;1:196-202.

5. Di Cera E. 2008. Thrombin.Mol. Aspects Med;29(4):203-54. doi: 10.1016/j.mam.2008.01.001.

6. Bishop P.D, Lewis K.B, Schultz J , Walker K.M. 2006. Comparison of Recombinant Human Thrombin and Plasma-Derived Human $\alpha$-Thrombin. Semin ThrombHemost;32: 086097DOI: 10.1055/s-2006-939558.

7. Cereghino J.Land J. M. Cregg. Heterologous protein expression in the methylotrophic yeast Pichia pastoris. FEMS Microbiol. Rev. 2000;24: 45-66.

8. Daly, R.\& Hearn,M.T.W. Expression fo heterologous proteins in Pichia pastoris: a useful experimental tool in protein engineering and production. J. Mol. Recognit. 2004;18: 119-138.

9. Watanabe, H., Yamasaki, K., KraghHansen, U., Tanase, S., Harada, K., Suenaga, A., Otagiri, M. In vitro and in vivo properties of recombinant human serum albumin from Pichia pastoris purified by a method of short processing time. Pharm. Res. 2001;18, 1775-1781.
10. Hardy, E., Martínez, E., Diago, D., Díaz R., González, D., and Herrera L. Large-scale production of recombinant hepatitis B surface antigen from Pichia pastoris. J. Biotechnol. 2000;77, 157167.

11. Invitrogen, A manual of methods for expresion of recombinant proteins in Pichia Pastoris, 2006. California.

12. Shabarni-Gaffar , Permana D, Rahmawati DP , Meirina TN, Syihab ABMI, Ismayana S, Subroto T, Suprijana O, Soemitro S. Effectof methanol inducer concentration and carbon source sorbitol and mannitol to the production of Saccharomycopsisfibuligera R64 $\alpha$-amylase in Pichiapastoris. Indonesia J Appl Chem. 2011; 13(2): 58-64.

13. Lowry, O.H., Rosenbrough, N.J., Farr, A.L., Randall, R.J. Protein measurement with Folin Phenol Reagent. J Biol Chem. 1951;193, pp. 265-275.

14. Inan, M., Meagher, M.M. Nonrepressing carbon sources for alcohol oxidase (AOX1) promoter of Pichia pastoris. J. Biosci. Bioengng. 2001; 92: 585-589. 